\title{
A bio-based epoxy resin by electrochemical modification of tall oil fatty acids
}

Goswinus H. M. de Kruijff, ${ }^{\dagger}$, Thorsten Goschler, ${ }^{\perp}$ Lukasz Derwich, ${ }^{\S}$ Nicole Beiser, ${ }^{\dagger}$ Oliver M. Türk ${ }^{\perp, \S}$ and Siegfried R. Waldvogel ${ }^{*}, \dagger, *$

$\uparrow$ Institute of Organic Chemistry, Johannes Gutenberg University Mainz, 55128 Mainz, Germany.

† Graduate School Material Science in Mainz, Johannes Gutenberg University Mainz, 55128 Mainz, Germany.

$\perp$ Technische Hochschule Bingen, Berlinstr. 109, 55411 Bingen am Rhein, Germany.

$\S$ Transferstelle Bingen TSB, Berlinstr. 107a, 55411 Bingen am Rhein, Germany.

* Corresponding Author E-mail: waldvogel@uni-mainz.de

\section{Electronic Supplementary Material}

11 pages, 9 figures, 2 tables

\section{Content}

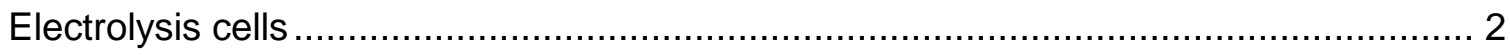

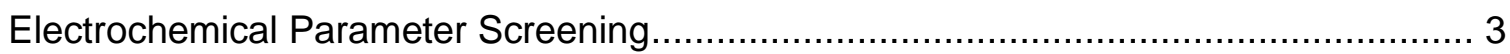

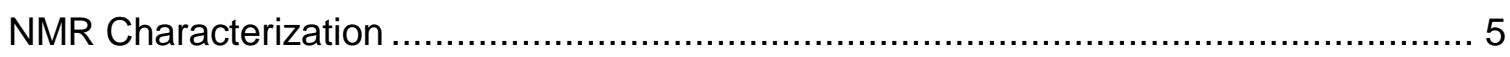

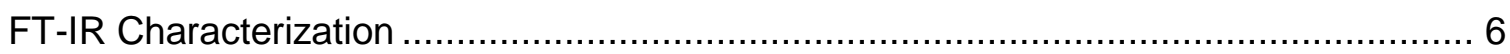

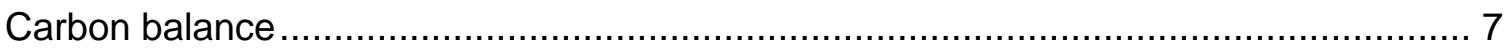

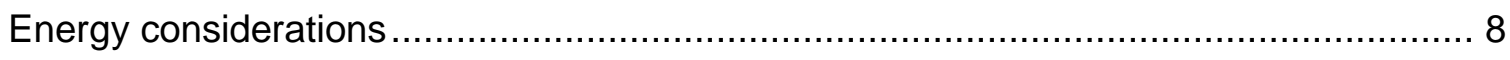

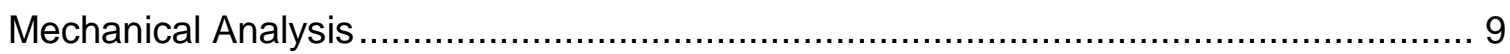

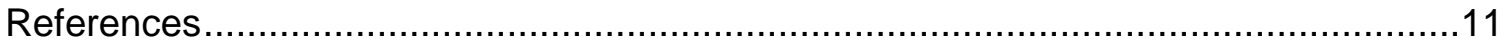




\section{Electrolysis cells}

Beaker-type cell $(25 \mathrm{~mL}$ or $200 \mathrm{~mL}$ ). The beaker-type cell $(25 \mathrm{~mL}$ or $200 \mathrm{~mL}$ ) consists of a simple glass beaker with or without cooling jacket and closed by a Teflon plug. This cap allows precise arrangement of the electrodes in a distance of $10 \mathrm{~mm}$. Dimensions of used electrodes were $7.0 \mathrm{~cm} \times 2.0 \mathrm{~cm} \times 0.2 \mathrm{~cm}$. The electrodes had upon immersion into the electrolyte an active surface of $8 \mathrm{~cm}^{2}$ for the $25 \mathrm{~mL}$ cell and $6 \mathrm{~cm}^{2}$ for the $200 \mathrm{~mL}$ cell. A four-channel HMP4040 (Rohde\&Schwarz GmbH \& Co. KG, Munich, Germany) or single-channel Z60-3.5 (TDK Lambda, Achern, Germany) was used as power supply. For the electrochemical reaction, isostatic graphite (SIGRAFINE ${ }^{\circledR}$ V2100, SGL Carbon, Bonn-Bad Godesberg, Germany) was used as electrode material. Terminal voltage in both beaker-type cells following General Protocol A typically is in the range of 4-6 V and following General Protocol B of 7-13 V.

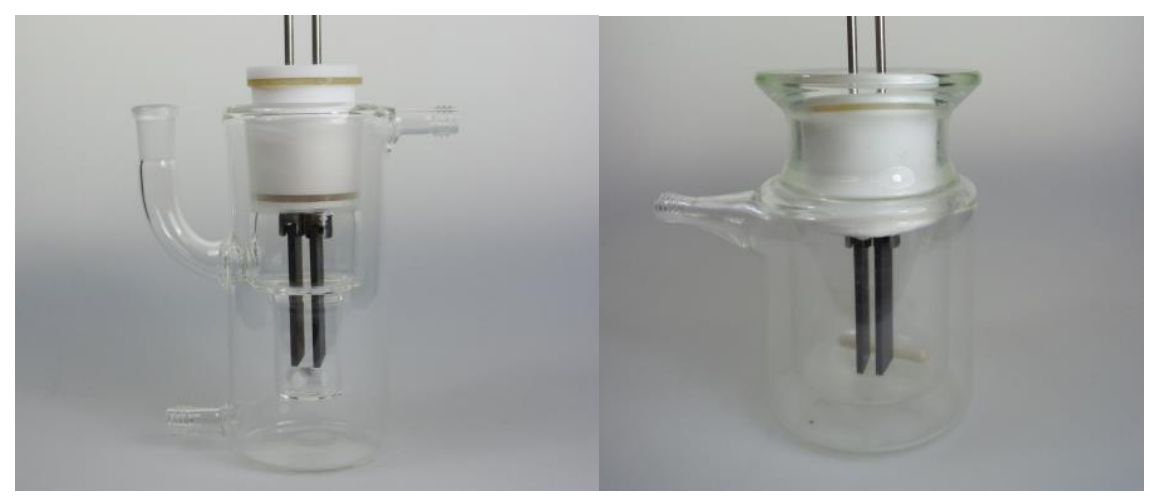

Figure S1: Double-jacketed beaker-type cell; left: $25 \mathrm{~mL}$; right: $200 \mathrm{~mL}$.

Beaker-type cell (1.5 L). The undivided 1.5 L vessel is equipped with a heating jacket, bottom outlet and thermometer. A stacked electrode setup of 6 isostatic graphite electrodes $(d=5 \mathrm{~mm})$ with alternating connectivity to power supply was used with a total surface area of $374 \mathrm{~cm}^{2}$ anodic and cathodic sites. For power supply, a TDK Lambda Genesys ${ }^{\text {TM }}$ GEN 30-50 was used providing a maximum of $1500 \mathrm{~W}$ at $30 \mathrm{~V} / 50 \mathrm{~A}$. The electrolysis was performed exclusively in well-ventilated fume hoods to prevent the formation of an explosive hydrogen air mixture.
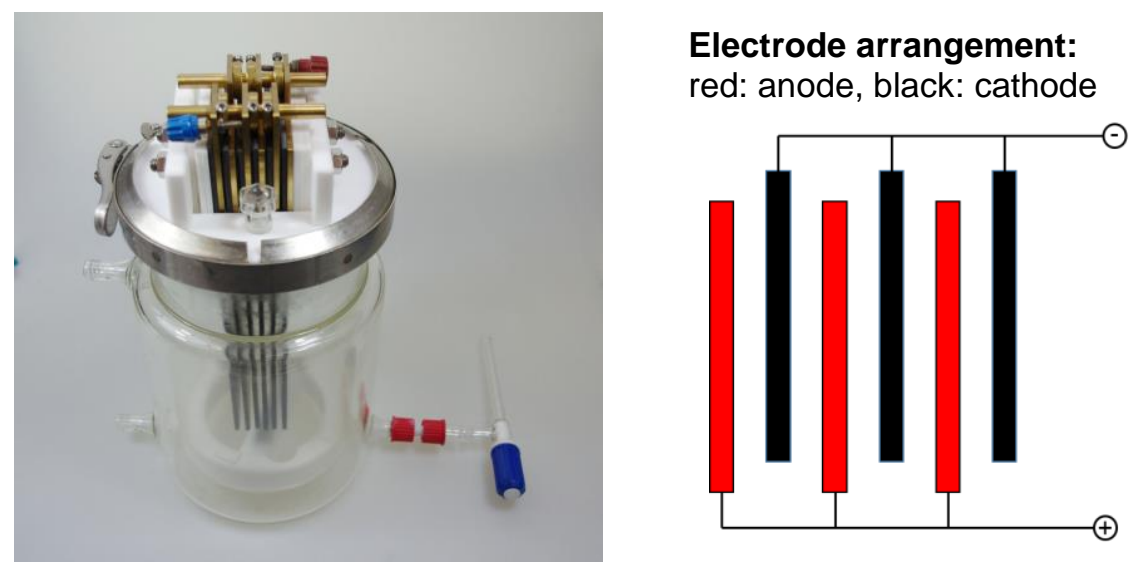

Figure S2: Double-jacketed $1500 \mathrm{~mL}$ beaker-type cell; left: assembled; right: technical illustration of the electrode arrangement. 


\section{Electrochemical Parameter Screening}

\section{Screening of charge equivalents for the anodic decarboxylation of TOFA (General Protocol A)}

Tall oil fatty acid (TOFA, $5 \mathrm{mmol}$ ) and sodium methoxide $(5 \mathrm{mmol})$ were transferred into an undivided double-jacketed $25 \mathrm{~mL}$ beaker-type electrolysis cell equipped with an isostatic graphite anode and an isostatic graphite cathode. Methanol was added until a volume of $20 \mathrm{~mL}$ was reached $(0.25 \mathrm{M})$. A constant current electrolysis with a current density of $20 \mathrm{~mA} / \mathrm{cm}^{2}$ was performed at $50^{\circ} \mathrm{C}$. After completion, the reaction solution was concentrated under reduced pressure, taken up in water $(50 \mathrm{~mL})$ and set to $\mathrm{pH} 3$ by adding aqueous $\mathrm{HCl}(10 \%)$. The aqueous phase was afterwards extracted twice with $50 \mathrm{~mL}$ of ethyl acetate. The combined organic phases were washed with brine and dried over $\mathrm{MgSO}_{4}$ and filtered. Evaporation of the solvent gave electrolyzed TOFA as a pale yellow oil.

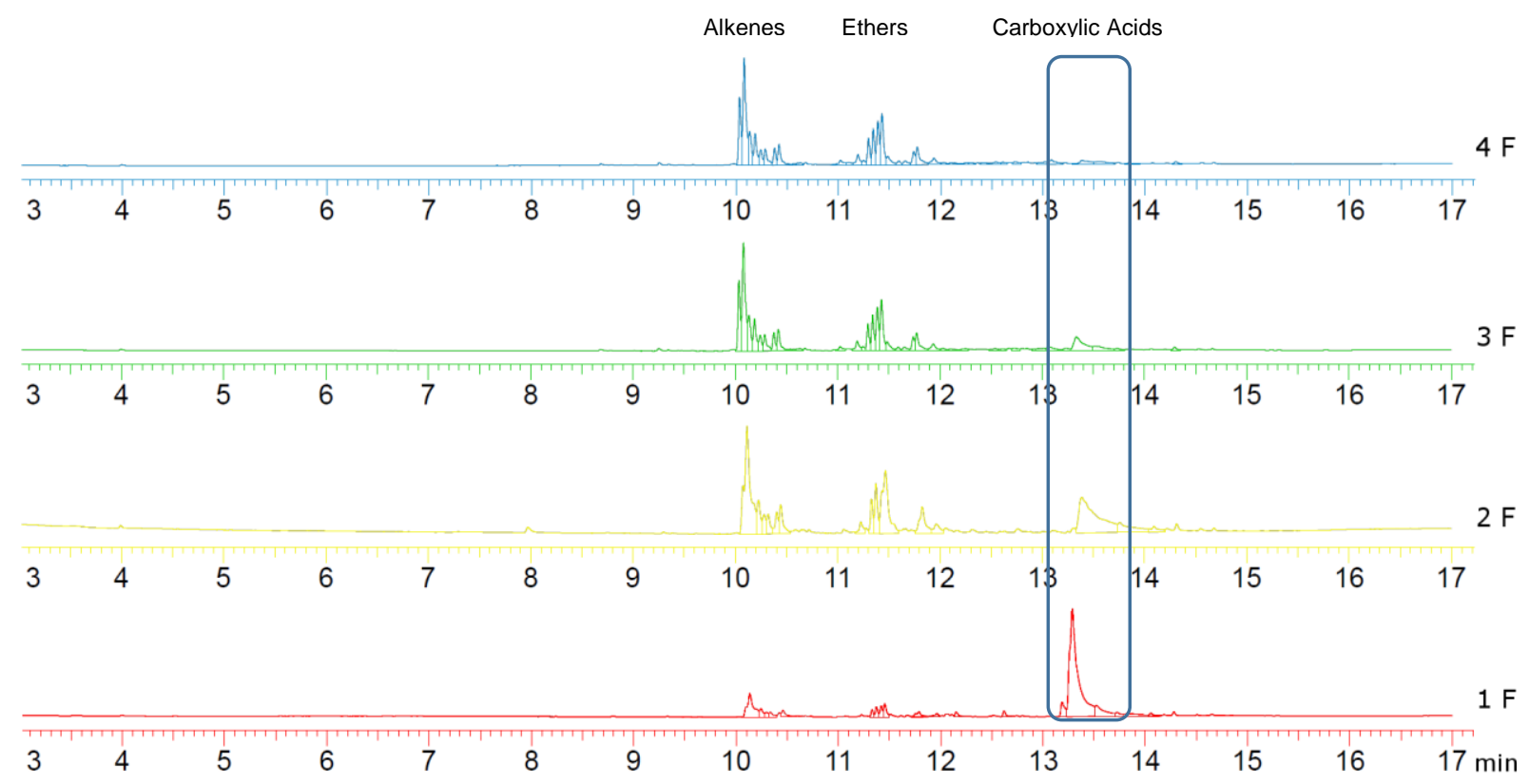

Figure S3: Influence of charge equivalents on TOFA electrolysis (GC chromatograms of crude product mixture).

In this setup, the starting material was completely consumed after slightly more than $3 \mathrm{~F}$ had passed. At a constant charge of $3 \mathrm{~F}$, the conversion decreased with decreasing concentration of TOFA (see below). 


\section{Screening of carboxylic acid concentration for the anodic decarboxylation of TOFA (General Protocol B)}

Tall oil fatty acid (TOFA) and sodium methoxide (1 eq.) were dissolved in methanol $(200 \mathrm{~mL})$ and transferred into an undivided double-jacketed $200 \mathrm{~mL}$ beaker-type electrolysis cell equipped with an isostatic graphite anode and an isostatic graphite cathode. A constant current electrolysis with a current density of $20 \mathrm{~mA} / \mathrm{cm}^{2}$ was performed at $50^{\circ} \mathrm{C}$. After a charge of $3 \mathrm{~F}$ had passed, the reaction solution was concentrated under reduced pressure, taken up in water (100 $\mathrm{mL}$ ) and set to $\mathrm{pH} 3$ by adding aqueous $\mathrm{HCl}(10 \%)$. The aqueous phase was afterwards extracted twice with $100 \mathrm{~mL}$ of ethyl acetate. The combined organic phases were washed with brine and dried over $\mathrm{MgSO}_{4}$ and filtered. Evaporation of the solvent gave electrolyzed TOFA as a pale yellow oil.

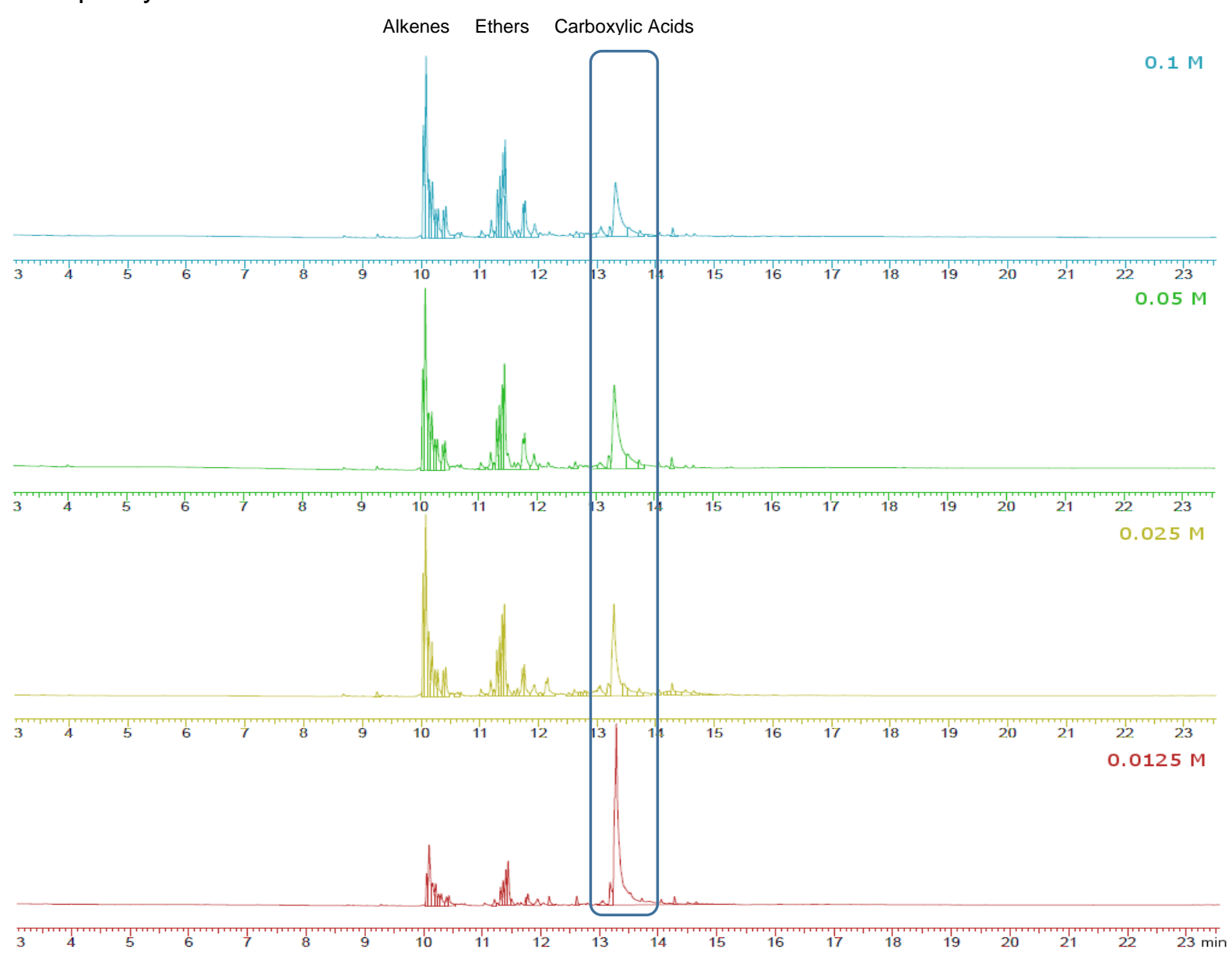

Figure S4: Influence of concentration on TOFA electrolysis (GC chromatograms of crude product mixture). 


\section{NMR Characterization}

The conversion of olefinic bonds by epoxidation was confirmed by NMR spectroscopy. The olefinic signals at 5-6 ppm ( ${ }^{1} \mathrm{H}$, blue $)$ and $110-140 \mathrm{ppm}\left({ }^{13} \mathrm{C}\right.$, blue $)$ of EL-TOFA are completely gone in ELPOXY-TOFA (black). A

(a)
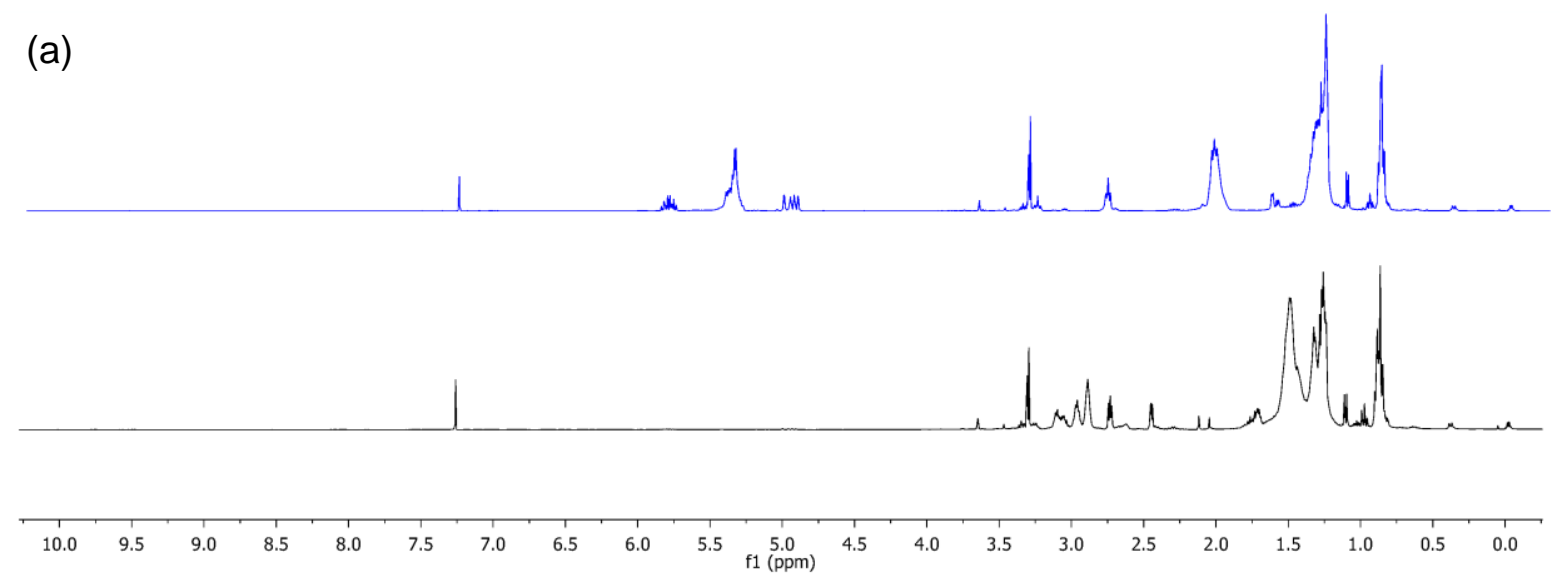

(b)

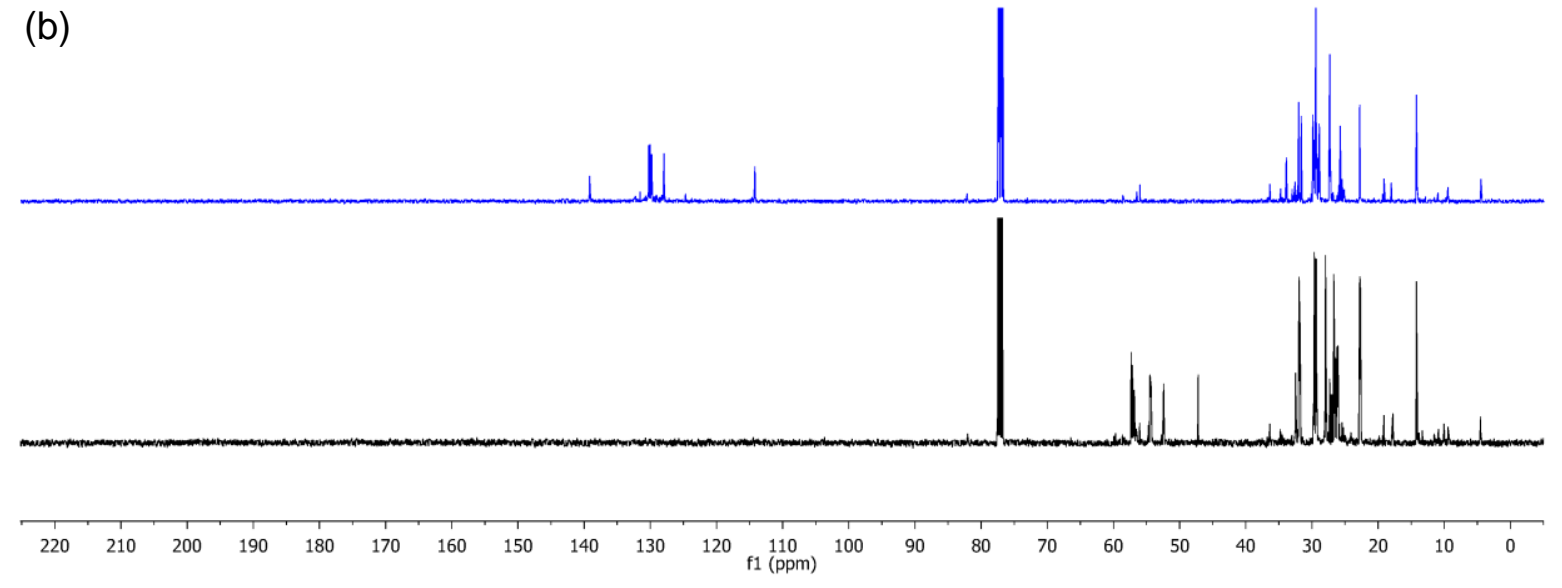

Figure S5: ${ }^{1} \mathrm{H}$ (a) and ${ }^{13} \mathrm{C}$ (b) spectra of EL-TOFA (blue) after electrolysis and ELPOXY-TOFA (black) subsequent epoxidation process. 


\section{FT-IR Characterization}

The FT-IR spectra of the starting material TOFA, the resin precursor ELTOFA and the epoxy resin ELPOXY-TOFA are shown in Fig. S6. The characteristic carbonyl absorbtion at $1706 \mathrm{~cm}^{-1}$ disappears after decarboxylative electrolysis. Likewise, the alkene $\mathrm{C}-\mathrm{H}$ stretch band at $3009 \mathrm{~cm}^{-1}$ is not observed in the ELPOXY-TOFA resin, indicating the conversion of olefinic bonds to oxiranes. The absorption peak at $1093 \mathrm{~cm}^{-1}$ is assigned to the $\mathrm{C}-\mathrm{O}-\mathrm{C}$ ether stretch in both methyl ether electrolysis by-product and oxirane. The sharp peak at $908 \mathrm{~cm}^{-1}$ for ELTOFA represents the out-of-plane monosubstituted alkene bend from terminal alkenes formed during electrolysis, which replaced by the broader absorption peak at $912 \mathrm{~cm}^{-1}$ representing the $\mathrm{C}-\mathrm{O}$ deformation of oxiranes after epoxidation to ELPOXY-TOFA. This is accompanied by the C-O-C stretch absorption peaks at 1261 and $824 \mathrm{~cm}^{-1}$.

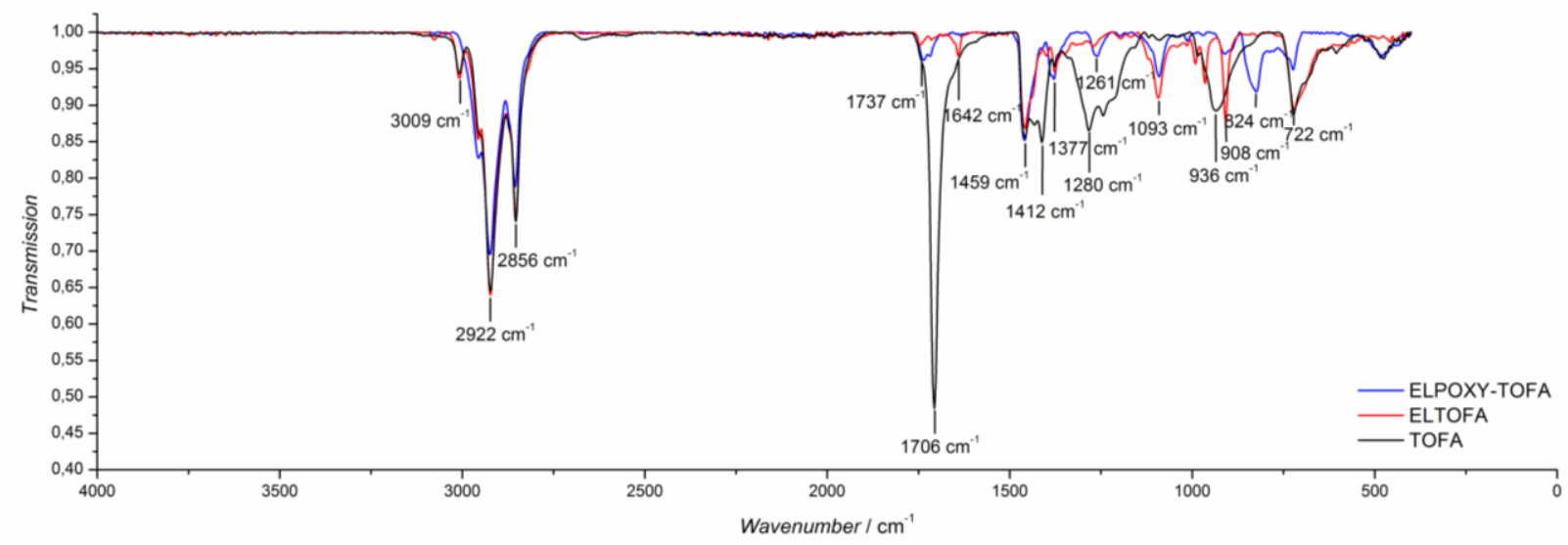

Figure S6: IR spectra of TOFA (black), EL-TOFA (red) and ELPOXY-TOFA (blue). 


\section{Carbon balance}

On the basis of the obtained experimental data, a carbon balance calculation was performed (Table S1). After electrolysis, $5.6 \%$ carbon is released as $\mathrm{CO}_{2}$ (inherent to the Kolbe decarboxylation). The largest proportion of $81.2 \%$ carbon ends up in the ELPOXY Olefin/Ether product, while a minor share of $13.2 \%$ carbon is lost as by-product and removed by distillation. After epoxidation, 99\% of the theoretical mass is recovered. Therefore, the bio-based carbon content of $98 \%$ is retained during epoxidation from EL-TOFA to ELPOXY-TOFA.

Table S1: Carbon balance calculation for the preparation of ELPOXY-TOFA.

$\begin{array}{lccrr}\text { Starting material } & \text { mass } & \text { amount of substance } & \text { carbon content } & \text { biobased carbon share } \\ \text { TOFA } & 91,3 \mathrm{~g} & 0,325 \mathrm{~mol} & 70,2 \mathrm{~g} & 100,0 \% \\ & & & & \\ \text { Electrolysis } & \text { mass } & \text { amount of substance } & \text { carbon content } & \text { biobased carbon share } \\ \mathrm{CO}_{2} \text { loss } & 14,3 \mathrm{~g} & 0,325 \mathrm{~mol} & 3,9 \mathrm{~g} & 5,6 \% \\ \text { Ether } & 33,0 \mathrm{~g} & 0,124 \mathrm{~mol} & 26,7 \mathrm{~g} & 35,9 \% \\ \quad \text { OMe incorporation } & 3,8 \mathrm{~g} & 0,124 \mathrm{~mol} & -1,5 \mathrm{~g} & 0,0 \% \\ \text { Olefins } & 36,7 \mathrm{~g} & 0,156 \mathrm{~mol} & 31,8 \mathrm{~g} & 45,3 \% \\ \text { By-Products } & & & 9,3 \mathrm{~g} & 13,2 \% \\ \text { Sum } & & & 70,2 \mathrm{~g} & 100,0 \%\end{array}$

\begin{tabular}{|c|c|}
\hline Experimenta & \\
\hline Olefins & $48 \% \mathrm{M}=235 \mathrm{~g} / \mathrm{mol}$ \\
\hline Ether & $38 \% \mathrm{M}=267 \mathrm{~g} / \mathrm{mol}$ \\
\hline By-Products & $14 \%$ \\
\hline Olefin/Ether & $1: 0.8$ \\
\hline
\end{tabular}

$\begin{array}{lcrrr}\text { Starting material } & \text { mass } & \text { amount of substance } & \text { carbon content } & \text { biobased carbon share } \\ \text { EL-TOFA } & 20,0 \mathrm{~g} & 0,082 \mathrm{~mol} & 17,1 \mathrm{~g} & 98,4 \%\end{array}$

$\begin{array}{lrl}\text { Experimental Data } & \\ \text { Olefins } & 72 \% \mathrm{M}=235 \mathrm{~g} / \mathrm{mol} \\ \text { Ether } & 28 \% \mathrm{M}=267 \mathrm{~g} / \mathrm{mol} \\ \mathrm{I}_{2} \text { number } & 217 \mathrm{~g} \\ \mathrm{C}=\mathrm{C}\left(\mathrm{I}_{2} \text { number }\right) & 0,171 \mathrm{~mol}\end{array}$




\section{Energy considerations}

The operating voltage of the $1.5 \mathrm{~L}$ electrolysis cell is $5 \mathrm{~V}$ at $7.48 \mathrm{~A}(37.4 \mathrm{~W}) .91 .3 \mathrm{~g}(3.25 \mathrm{~mol})$ TOFA were electrolyzed for $3.5 \mathrm{~h}$ (until a charge of $3 \mathrm{~F}$ had passed). This equals an energy input of $0.131 \mathrm{kWh}$. Based on $35.5 \mathrm{~g}$ obtained EL-TOFA that was used in the subsequent epoxidation, this corresponds to a current efficiency of $32 \%$ and an energy input of $13.3 \mathrm{~kJ} / \mathrm{g}$ (3.69 Wh/g).

Average industrial electricity prices in 2017 were 68.8 \$US/MWh (US) and 115.8 \$US/MWh (EU). This corresponds to $0.92 \phi U S / m o l ~(U S)$ and $1.6 \mathrm{\phi US} / \mathrm{mol}$ (EU) electrons used as oxidizing agent operating at $5 \mathrm{~V}$, by far outcompeting classical oxidizing agents such as $\mathrm{H}_{2} \mathrm{O}_{2}$ (Table S2).

Table S2: Oxidizing agent costs for common laboratory oxidizers per mole.

Oxidizing agent

\begin{tabular}{|l|l|l}
\hline $1^{\mathrm{a}}$ & Electricity @5V (Industrial, US) & 0.009 \\
\hline $2^{\mathrm{a}}$ & Electricity @5V (Industrial, EU) & 0.016 \\
\hline $3^{\mathrm{b}}$ & Electricity @5V (Household, US) & 0.017 \\
\hline $4^{\mathrm{b}}$ & Electricity @5V (Household, EU) & 0.030 \\
\hline $5^{\mathrm{c}}$ & Hydrogen peroxide (aq., 30\%) & 13.60 \\
\hline $6^{\mathrm{d}}$ & Oxygen, 2.5 (99.5\%) & 13.86 \\
\hline $7^{\mathrm{d}}$ & Oxygen, 4.5 (99.995\%) & 101.31 \\
\hline $8^{\mathrm{c}}$ & lodine & 110.00 \\
\hline $9^{\mathrm{c}}$ & Oxone & 7.82 \\
\hline $10^{\mathrm{c}}$ & tBuOOH & 361.93 \\
\hline $11^{\mathrm{c}}$ & Iron trichloride & 8.81 \\
\hline $12^{\mathrm{c}}$ & Potassium peroxodisulfate & 21.63 \\
\hline $13^{\mathrm{c}}$ & Potassium hexacyanoferrate(III) & 52.25 \\
\hline
\end{tabular}

€EUR-\$US exchange rate: 1,124 (wallstreet-online.de, 24.04.2019), a) from "Electric power annual", released by the US Department of Energy on October 22, 2018, b) from "Energy prices and costs in Europe", SWD, released by the European Commission in January 2019, c) Prices from Sigma Aldrich, Germany, 24.04.2019, d) Westfalen AG. 


\section{Mechanical Analysis}

Curing of ELPOXY-TOFA resin was monitored in a continuos DMA measurement using a DMA 242 E Artemis (Netzsch, Germany) equipped with a sample holder and a ball-shaped pushrod. In this setup, the change in viscoelastic properties during the curing reaction is evaluated as a function of compression force.

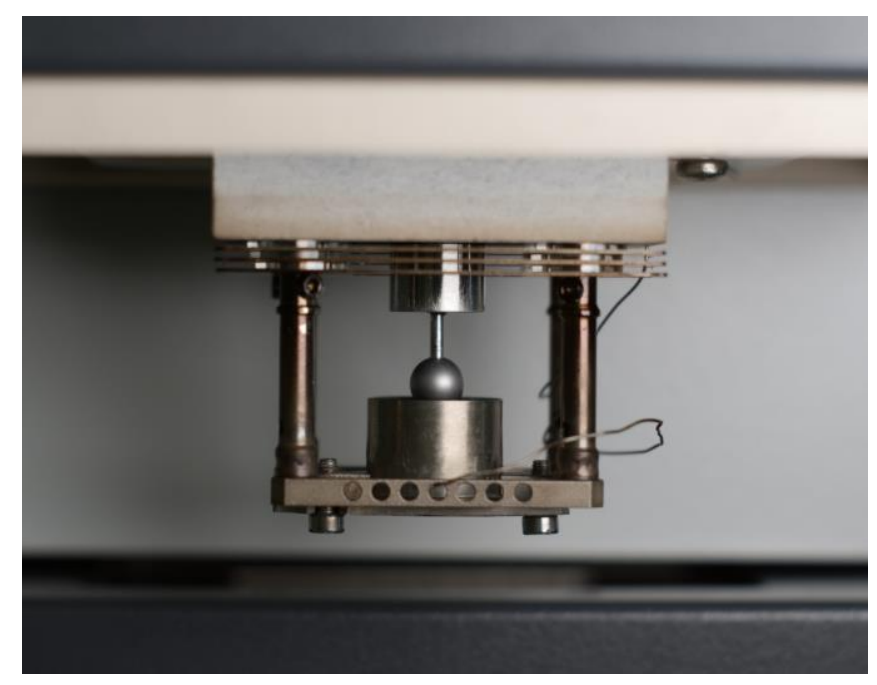

Figure S7: DMA setup for evaluation of viscoelastic properties.

Isothermal curing at $100^{\circ} \mathrm{C}$ of ELPOXY-TOFA with MTHPA in stoichiometric ratio of epoxy/anhydride $1: 1$ in presence of $3 \mathrm{wt} \%$ imidazol in 1,3-butanediol (1:2) was performed in the DMA setup decribed above (Fig. S8). After $2400 \mathrm{~min}$, the compression force stayed constant. Consequently, no further cross-linking of the epoxy material took place.

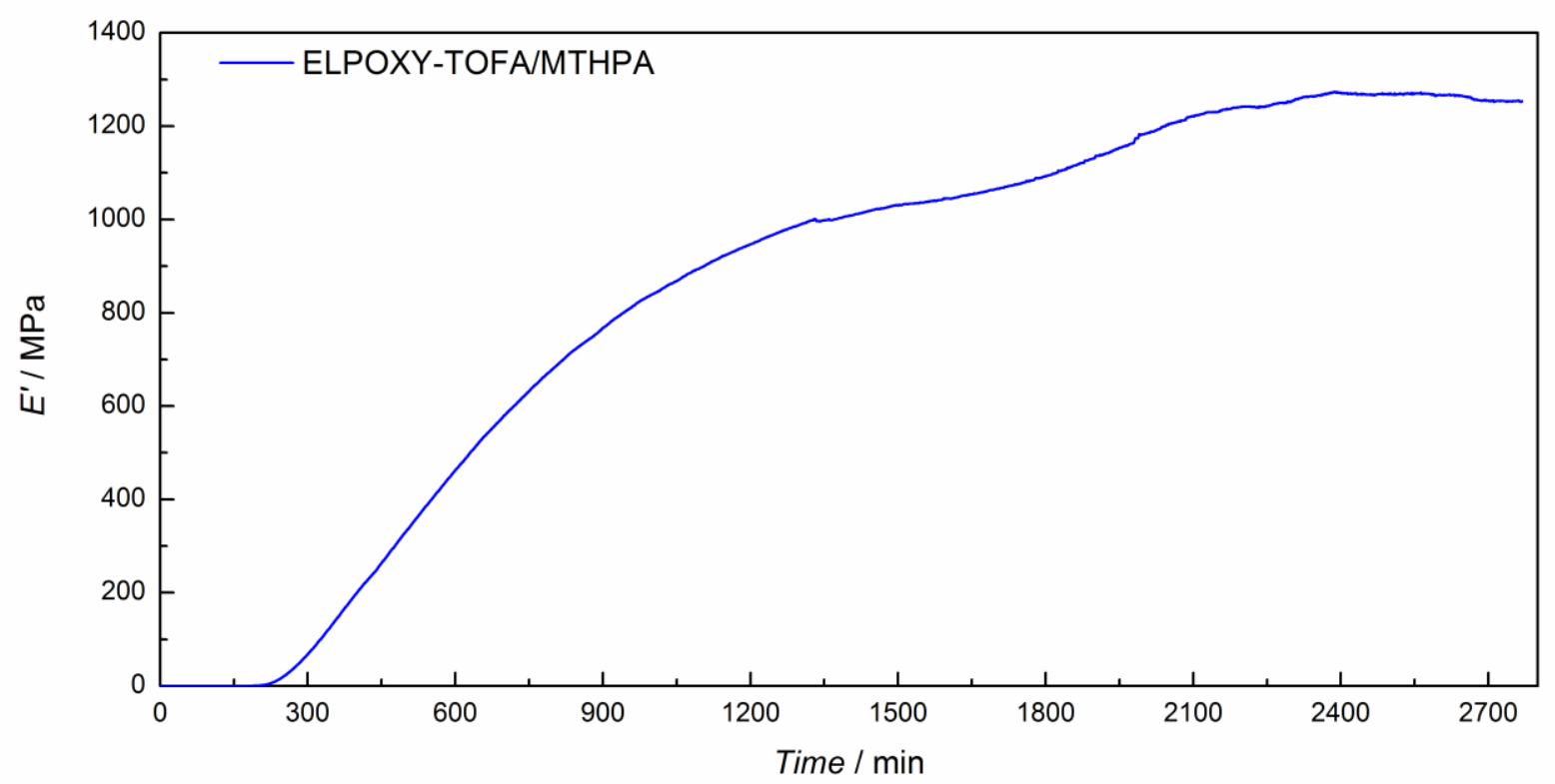

Figure S8: Compression DMA for isothermal curing of ELPOXY-TOFA/MTHPA at $100^{\circ} \mathrm{C}$. 
The curing of the epoxy resin was performed using the anhydride hardener (MTHPA, MNA, DDSA) in stoichiometric ratio of epoxy/anhydride $1: 1$ in presence of $3 \mathrm{wt} \%$ imidazol in 1,3butanediol (1:2). The samples were homogenized by thorough mixing before analysis and curing. For the preparation of test specimen, the epoxy-anhydride mixture was poured into a silicon mold. The dimensions of the resulting specimen were $60 \mathrm{~mm} \times 10 \mathrm{~mm} \times 3.2 \mathrm{~mm}$ for DMA testing, standardized dog-bone shaped specimen (type $1 \mathrm{~A}$ ) for tensile testing according DIN EN ISO $527-2^{[1]}$ and standardized rectangular $80 \mathrm{~mm} \times 10 \mathrm{~mm} \times 4 \mathrm{~mm}$ specimen for determination of flexural properties according DIN EN ISO $178^{[2]}$ and impact properties according DIN EN ISO $179^{[3]}$ for determination of impact properties. Curing was performed in an oven at $100^{\circ} \mathrm{C}$ for $24 \mathrm{~h}$. After cooling to room temperature, the specimen were kept at 100 and $120^{\circ} \mathrm{C}$ for one hour each and additional 2 hours at $140^{\circ} \mathrm{C}$.

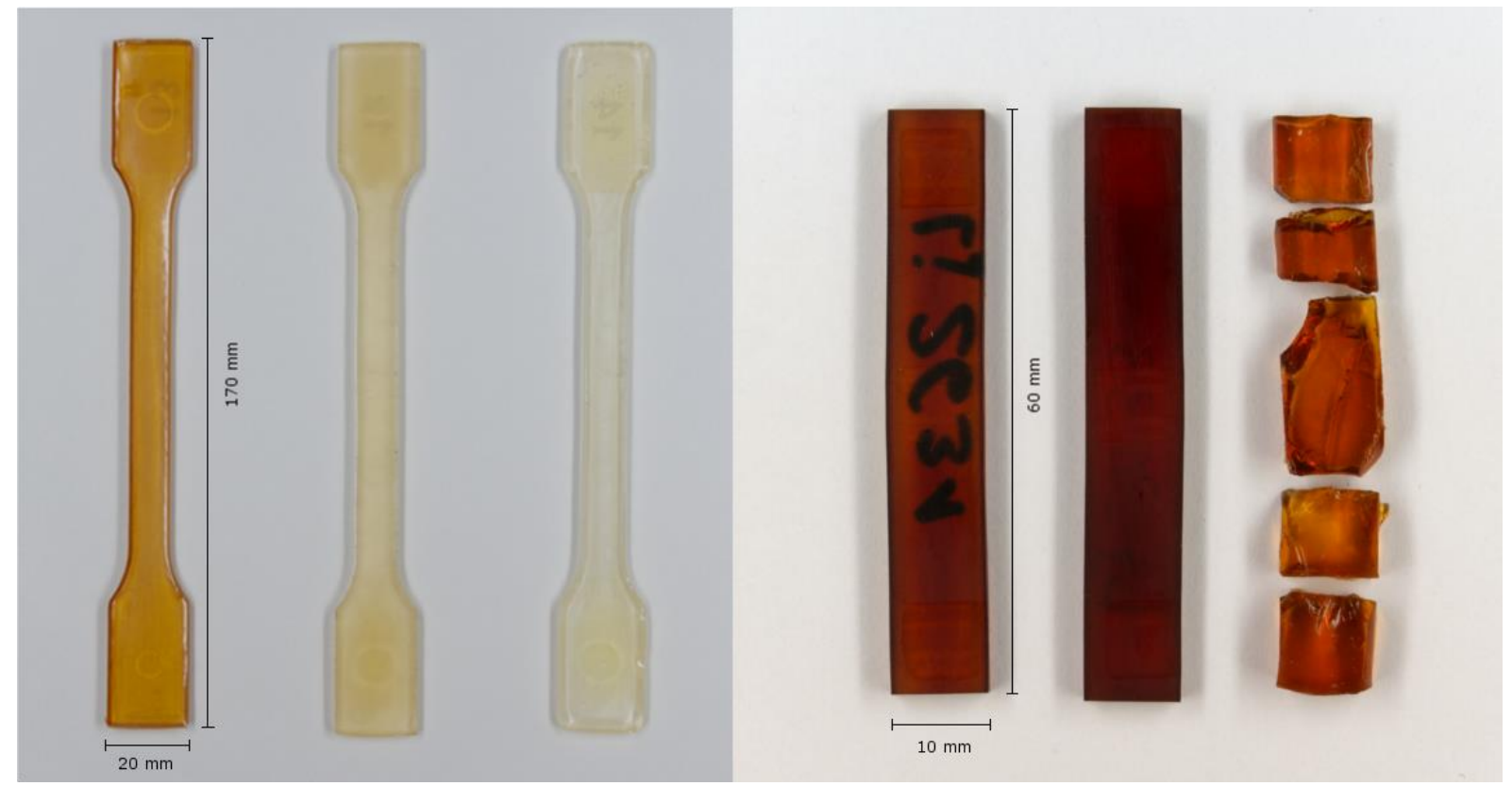

Figure S9: Test specimen, left: dog-bone shaped for tensile testing (ELPOXY-TOFA, PTP cured with MTHPA), right: bar-shaped DMA specimen of ELPOXY-TOFA cured with MTHPA, MNA and DDSA, respectively (deformed after recovery from DMA measurement sample holder). 


\section{References}

[1] DIN EN ISO 527-2:2012-02, Plastics - Determination of tensile properties - Part 2: Test conditions for moulding and extrusion plastics, 2012, Standard, Beuth Verlag GmbH, Berlin.

[2] DIN EN ISO 178:2013-09, Plastics - Determination of flexural properties, 2013, Standard, Beuth Verlag $\mathrm{GmbH}$, Berlin.

[3] DIN EN ISO 179-1:2010-11, Plastics - Determination of Charpy impact properties - Part 1: Non-instrumented impact test, 2010, Standard, Beuth Verlag GmbH, Berlin. 